\title{
PREIMPLANTATION GENETIC DIAGNOSIS IN CATTLE: A REVIEW
}

\author{
S. BODÓ ${ }^{1,2, *}$, B. BARANYAI ${ }^{2}$, Elen GÓCZA ${ }^{2}$, J. DOHY $^{3}$ and Merja MARKKULA ${ }^{1}$ \\ ${ }^{1}$ Agricultural Research Centre of Finland, MTT, FIN-31600 Jokioinen, Finland; \\ ${ }^{2}$ Agricultural Biotechnology Centre, H-2100 Gödöllö, Hungary; ${ }^{3}$ Research Group for \\ Animal Breeding of the Hungarian Academy of Sciences, H-2100 Gödöllö, Hungary
}

(Received May 8, 2000; accepted October 30, 2000)

\begin{abstract}
Preimplantation Genetic Diagnosis (PGD) is reviewed and novel fields where it may be applied are investigated. Technical advances of PGD in cattle embryos have already enabled its integration as a part of the MOET (Multiple Ovulation Embryo Transfer) breeding system. PGD for well-defined selection targets can enhance cattle breeding and embryo trade. It allows embryo selection according to their sex, and it may be used to breed special cow lines, or top bulls, by selecting embryos for valuable production traits using Marker Assisted Selection (MAS). A good allelic profile and/or the insertion of a transgene can be detected by PGD. This review article presents the technical requirements for PGD, and shows that this biotechnological method has great economic potential.
\end{abstract}

Key words: Preimplantation genetic diagnosis, embryo, cattle

Using artificial insemination (AI), a bull can sire 10,000 or more of $\mathrm{f}$ spring, while an elite cow normally produces only one calf per year. Since the female contribution to genetic progress is consequently low, large-scale embryo production from elite females and their subsequent transfer into recipient dams would greatly increase the rate of genetic improvement in selection herds. By $\mathrm{r}$ educing the generation interval, an even higher genetic gain could be obtained: if the next generation is produced from oocyte donor heifers, the generation inte rval is only two years in cows. Each year, about $90 \%$ of embryos commercially transferred into recipient cattle are derived from MOET (Heyman, 1999). More embryos from elite heifers or cows can be obtained by in vitro embryo production (IVP), which is not only the basis for intensive cattle breeding, but also of sexing and diagnosis of genetic diseases and markers of economically important production traits before the embryos are transferred into recipient females.

${ }^{*}$ Corresponding author: Agricultural Biotechnology Centre, P.O. Box 411, H-2001 Gödöllő, Hungary; E-mail: bodo@abc.hu; Fax: +36 (28) 430-647 


\section{Embryo production in cattle}

Bovine embryos may be obtained either by flushing or by IVP. For flus hing, donors are subjected to superovulation treatment. On the average, five tran sferable embryos are obtained per flushing (Heyman, 1999). It may be repeated every fifth or sixth week. For IVP, the oocytes are collected from ovaries of slaughtered animals or repeatedly by ultrasound-guided aspiration of ovarian follicles, using ovum pick-up (OPU) from living heifers or cows (Bols et al., 1995). For intensive nucleus herd breeding, OPU is applied to Ayrshire cattle in Finland, and to Holstein-Friesians in France, Netherlands, Canada and the USA.

To produce embryos in vitro, the oocytes must undergo maturation, fertil isation and embryo culture. Both in vivo and in vitro, the embryos reach blastocyst stage one week after fertilisation, and are ready for transfer into a recipient heifer or cow. The first calves from in vitro produced embryos were born 18 years ago (Brackett et al., 1982). In 1997, 6\% of embryos transferred in Europe were produced in vitro, while in 1998 that ratio was 10\% (Heyman, 1999). The 'large-scale' embryo production from slaughtered oocyte donors is used to study preimplantation embryo development or to develop new methods.

\section{Use of Preimplantation Genetic Diagnosis (PGD)}

During preimplantation development, mammalian embryos can be split in half (Ozil et al., 1982) or some cells may be separated without compromising development of the remaining embryos (Wilton and Trounson, 1989). All cells are totipotent during the first three cell cycles to the fifth day of development. Separated cells are used in the PGD.

PGD was first used in medicine to screen genetic disorders in human e mbryos. This technique developed rapidly, simultaneously with the invention of $\mathrm{c} y-$ tological and molecular analysis techniques. In animal breeding, the first applic ation of PGD was the sex determination of embryos before transfer (Herr et al., 1990). Today, it is possible to detect alleles of major genes with high breeding i mportance in order to identify the best embryos for transfer. PGD must comprise $\mathrm{r}$ eliable methods for the micromanipulation of the embryos and sensitive gene dete ction techniques.

\section{Techniques of PGD}

\section{Embryo biopsy}

The micromanipulation when a microblade or a narrow glass needle is used to split the embryo and the zona pellucida is called embryo microsection. In blastocysts, it results in two unequally sized demi-embryos: trophectodermal cells (10-30\% of the original embryo) are used for PGD, and the other half with the inner cell mass and reduced number of trophectodermal cells is transferred to 
the recipient (Bredbacka, 1998). It can also be performed on the farm without a micromanipulator, simply by u sing a stereomicroscope (Bredbacka et al., 1995).

Microaspiration was first developed in mice (Wilton and Trounson, 1989). Using a micromanipulator, 1-3 blastomeres are removed from an early morula through a small slit (approximately $30 \mu \mathrm{m}$ ) in the zona pellucida by a narrow glass capillary. Thus, the zona pellucida is not removed and remains to protect the biopsied embryo against mechanical damage and contamination.

Microaspiration is preferred if the analyses take more than a few hours and embryos are transferred freshly or in batches when the biopsied 8-16 cell stage embryos are to be cryopreserved later at the blastocyst stage (Vajta et al., 1997). A disadvantage of this technique could be the increased chance of misdetection due to the small amount of the genetic material in the sample. Moreover, at the blastocyst stage, the use of microaspiration resulted in a significantly lower e mbryo development and reduced pregnancy rates on day 30 and day 60 compared to microsection (Carbonneau et al., 1997).

\section{Gene analysis}

Karyotyping. The first diagnostic technique used in PGD was karyotyping the metaphase chromosomes of a demi-embryo. Sex chromosomes or chrom osomal abnormalities, e.g. duplications and translocations, were investigated with traditional chromosome labelling methods (Anderson, 1985; Picard et al., 1985). The first calves from sexed embryos were born in 1985 (Picard et al., 1985). Subsequent to this laborious method (Seike et al., 1990; Yadav et al., 1990) the monoclonal H-Y antibody test (Anderson, 1987; Wachtel et al., 1988) was developed in the 1980s for sex determination, that proved not to be reliable in practice for cattle compared to other novel methods.

Polymerase Chain Reaction (PCR). The invention of a very sensitive new gene detection method based on enzymatic amplification of known sequences of DNA by PCR (Mullis and Faloona, 1987), and its application made PGD fast and easy. PCR, a highly sensitive, reliable and fast detection method - it takes only a few hours - enables the investigation of genes in a limited number of e mbryonic cells. The amplification products are detected by gel electrophoresis or directly in the amplification reaction tube (Bredbacka et al., 1995).

Even a single gene copy can be detected for clinical research and mutations and sequence polymorphisms can be analysed (Wong et al., 1987; Vosberg, 1989). It has been successfully applied in human (Handyside et al., 1989) and mouse embryonic cells (Bradbury et al., 1990). For sex determination, the PCR reaction primers are designed to detect sequences within the sex chromosomes. The first PCR sexing method which resulted in calves born, was published ten years ago (Herr et al., 1990). Subsequently, reliable PCR methods were deve 1oped for bovine embryo sexing (Cotinot et al., 1991; Peura et al., 1991; Bred- 
backa et al., 1995). In 1993, Hungarian researchers published their own bovine sexing method (Macháty et al., 1993).

Fluorescent In Situ Hybridisation (FISH). FISH gives information not only about a gene but also about its location on a chromosome. The probes for the target DNA are synthesised with incorporated fluorescent molecules or ant igen sites which are then hybridised with the target sequences. Direct visualis ation of the relative position of the hybridised probes is possible using fluore scence microscopy. FISH can reveal chromosomal aberrations, such as aneuploidy, mosaicism, triploidy and translocation. FISH ( Penketh et al., 1989) or the combination of FISH with PCR (Munné et al., 1994) has been used successfully for PGD in human diagnostics. The first child tested using PGD for a genetic disorder was born in 1992 (Handyside et al., 1992).

\section{Use of PGD in cattle breeding}

Embryo sexing is applied in practice, e.g. integrated in nucleus breeding systems (Fig. 1).

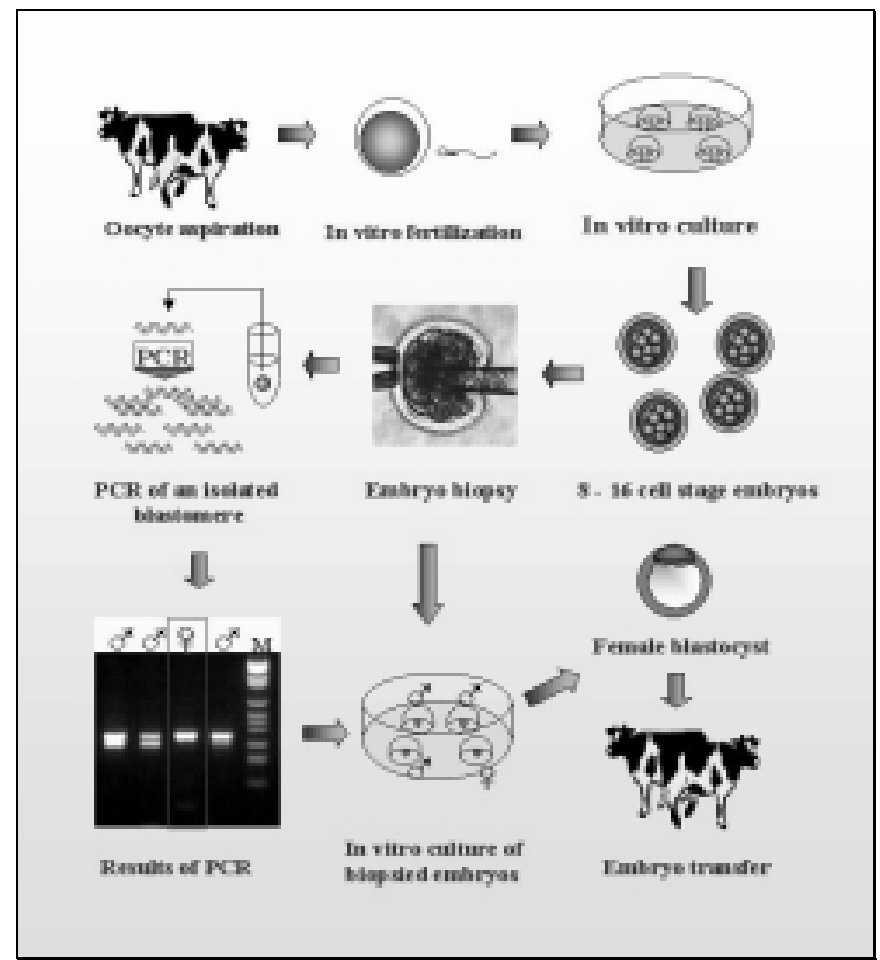

Fig. 1. Steps for sexing bovine OPU embryos by PCR with two sets of primers at the Agricultural Research Centre of Finland 
Besides detection of the sex, there are other opportunities of using PGD.

Cattle genome analysis and gene mapping reveals the genetic basis of i nherited traits. Quantitative Trait Loci (QTL) analysis, application of markerassisted selection and fine mapping of promising areas in the genome can $\mathrm{d}$ irectly benefit cattle breeding (Fésüs, 1997). For instance, cows homozygous for the kappa-casein B-allele, might be very valuable for the dairy industry. Such a line can be created in only one generation, directly from kappa-casein heteroz $\mathrm{y}$ gotes that are excellent in other breeding qualities, using PGD to detect the Ballele. The homozygote and heterozygote embryos could be transferred into di fferent populations. The price of diagnosed embryos could depend on the allele combination. New analytical probes such as multiplex genome analysis allows the simultaneous detection of several different genes (Hochman et al., 1996). Some important traits (e.g. sex and casein) can be detected together (Agrawala et al., 1992; Schellander et al., 1993), thus homozygous 'casein bulls', bull dams and dairy cows can be produced.

\section{Transgene detection}

As well as sex determination, the integration of a transgene into the g enome of an embryo has been investigated with PGD ( Horvat et al., 1993; Hyttinen et al., 1994; Hyttinen et al., 1996). PCR primers have been designed to a mplify both a sex-specific gene and the transgene in the same reaction. Only tran sgenic and preferably male embryos were transferred to a recipient. The adva ntage is the rapid selection of embryos and a financial saving by reducing the number of recipients. The use of fluorescent protein genes (e.g. the green flu orescent protein gene) as transgene markers is an additional tool besides PCR for PGD. Using a fluorescence microscope, it is possible to detect the expression of the marker gene in situ, and to obtain information about the expression profile of the transgene before embryo transfer (Chan et al., 1999).

\section{Genetic disorders}

A possible future application of PGD in cattle is the detection of inherited genetic disorders. In cattle breeding, a bull used for AI, which carries an und etected deleterious trait, is able to transmit a genetic defect widely. Diagnostic tests have been developed to screen the bulls, but PGD can be a powerful tool in a new selection method for screening carrier embryos. The traditional method, whereby the heterozygous carriers are eliminated gradually, from generation to generation, is very expensive. Using PGD, an oocyte- or embryo-donor herd with a high breeding value may become free of the disorder in one generation. Sens itive PCR probes developed to detect six important genetic disorders in adult ca ttle are already available. 
The most important genetic disorder, a monofactorial recessive-lethal d efect, is Bovine Leukocyte Adhesion Deficiency or BLAD (Jánosa et al., 1999). In US, $14.1 \%$ of the bulls and $5.8 \%$ of the dams of the Holstein breed were dia gnosed as heterozygote carriers in 1992 . The ratios were $21.4 \%$ and $4.66 \%$ in Denmark (Jörgensen et al., 1993), and $11.1 \%$ and $9.8 \%$ respectively in Hungary (Zsolnai and Fésüs, 1996). Hungarian researchers have developed a reliable PCR-RFLP method (Zsolnai and Fésüs, 1997). A multiplex PCR test was also developed by the same group which was also able to identify the casein alleles (Zsolnai and Fésüs, 1996).

Argininosuccinate Synthetase Deficiency or Citrullinaemia exhibits autosomal recessive inheritance in Holstein cattle. Affected calves are unable to e xcrete ammonia and display neurological degradation leading to death within one week after the birth (Harper et al., 1986). Discovered in Australia, citrullinaemia was traced to an American bull named Gray-View Crisscross that was used during the 1960s. In 1990 in the US a total of 367 top Holstein bulls were tested, with one carrier identified. This corresponds to an incidence of 0.3 percent and, based on his usage, to an incidence of less than 0.5 percent among Holstein $\mathrm{f} \mathrm{e}$ males in the country. This incidence is much lower than the 10 percent estimated for Australian cattle (Robinson and Shanks, 1993). The PCR test for citrullina emia was first applied in 1991 (Thomsen and Nielsen, 1991).

Deficiency of Uridine Monophosphate Synthetase (DUMPS) causes embryo mortality approximately 40 days after conception in $25 \%$ of matings between carriers in the Holstein breed. DUMPS testing began in 1988. Most carriers identified in North America and Europe were offspring of the fifth best and extensively used U.S. Holstein bull (according to TPI), namely Happy-Herd Beautician. The higher percentage of carriers in Europe compared to North America (34 percent vs. 17 percent) reflects the fact that more animals having a close relationship to known carriers were submitted for testing in Europe. The testing program also detected carriers in a second sire line (Shanks and Robi nson, 1993). The first results of the PCR test were published in 1994 (Schwenger et al., 1994). In Hungary, only two carriers out of 1151 animals tested were found $(0.17 \%)$. One was an imported bull that was never used for AI, while the other was a bull-rearing dam. The low incidence of the disease does not support a large-scale test for DUMPS in Hungary (Fésüs et al., 1999).

Myophosphorylase Deficiency causes muscular weakness and dehydration in the Charolais breed. The disorder is analogous with McArdle's disease in humans, and the investigation of the cattle disorder became a model for human therapy. After creating the cDNA from the mutant gene in 1996, the genetic test was published two years later (Bilstrom et al., 1998).

Bovine Alpha-Mannosidosis is a breed-specific mutation that arrests gl ycoprotein storage in the Galloway, Angus, Murray Grey and Brangus breeds. 
With a new PCR test, 5.4\% heterozygote carriers were detected in imported Red Angus cattle in Australia (Berg et al., 1997).

A parallel detection with simultaneous genetic typing of genetic diseases in embryos can be achieved by using a multiplex PCR following biopsy ( Schwerin et al., 1994).

\section{A PGD selection-preferred breeding system}

In cattle breeding, the genetic gain is increased by shortening the gener ation interval using MOET and related embryo techniques (OPU, IVP and cloning). Traditional selection methods (based on testing breeding values of adults) can be combined with gene selection of embryos. Figure 2 shows the integration of new methods of embryology and biotechnology with the traditional methods.

These data suggest that by increasing collaborations between applied an imal reproduction groups, a greater economic benefit will result.

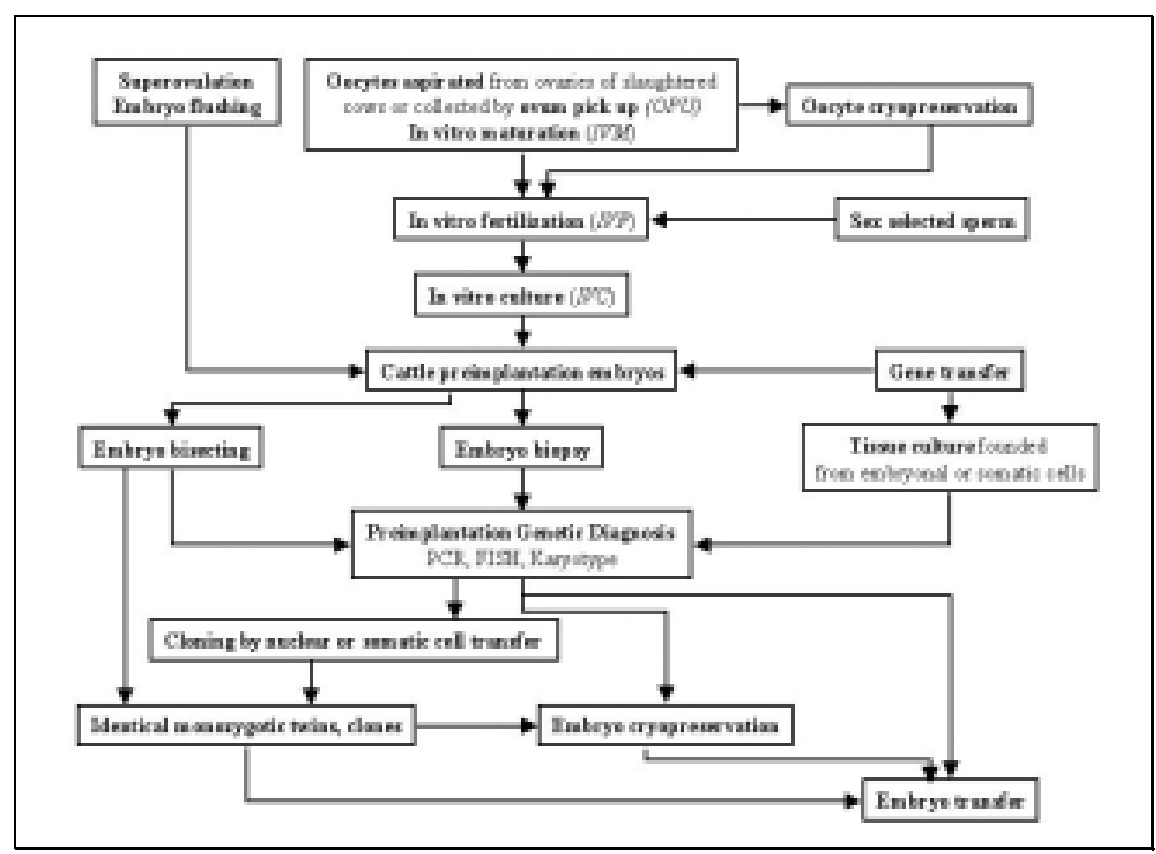

Fig. 2. PGD among new methods of applied embryology

Integrating the elements required for PGD, a breeding scheme can be ou tlined which results in the production of breeding cattle with certain traits known before their birth. The implementation and operation of this system needs state and private resources. The launch of a biotechnology-based animal breeding pr ogram using PGD needs the integration of several fields, as shown in Fig. 3. 


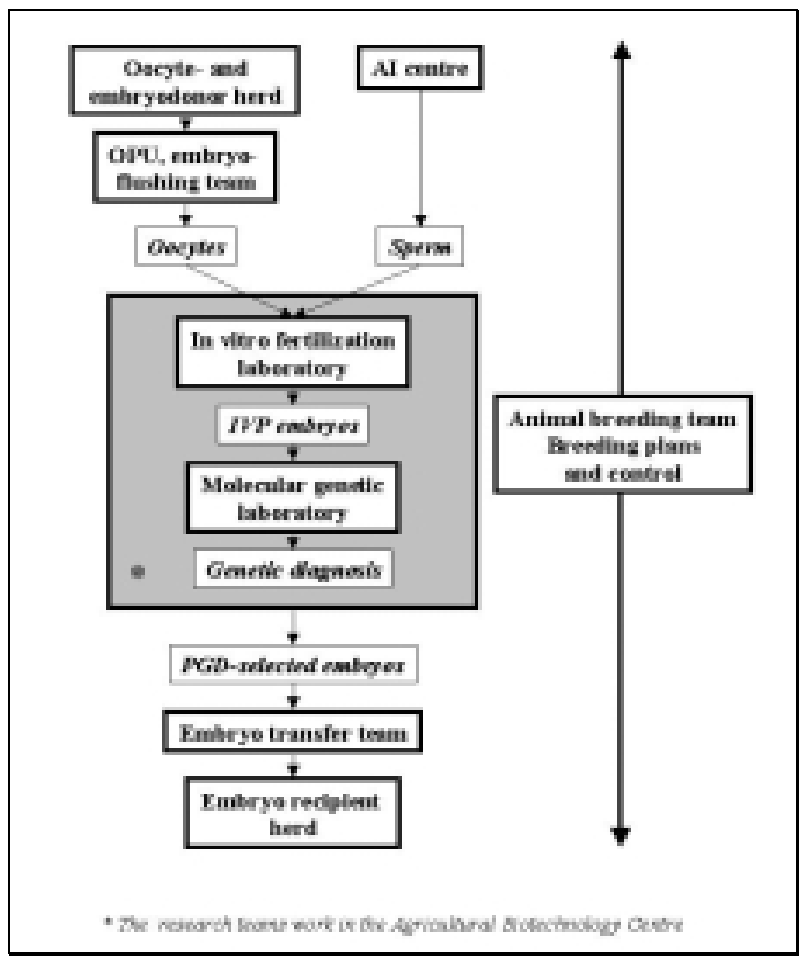

Fig. 3. The integrated breeding system for PGD

\section{Summary}

In practice, the application of embryo production and PGD requires cooperation between research, breeding and commerce. Intensive embryo produ ction enhances genetic gain in production traits and reduces the generation inte $\mathrm{r}$ val that further improves the economic result. These techniques, as well as in vitro embryo production and embryo sexing, are already applied in several bree ding programs. The cattle embryos can also be screened for inherited genetic di sorders and the carriers can be excluded from breeding in one generation.

This new integrated breeding scheme - based on the latest results of an imal biotechnology - is economically advantageous, and its application may e nable Hungarian animal husbandry to integrate with European cattle breeding and embryo trade.

\section{Acknowledgements}

The authors would like to thank Alexander Makarevich and Simon Boa for their comments and critical reading of the manuscript. 


\section{References}

Agrawala, P., Wagner, V. and Geldermann, H. (1992): Sex determination and milk protein genotyping of preimplantation stage bovine embryos using multiplex PCR. Theriogenology $\mathbf{3 8}$, 969-978.

Anderson, G. (1985): Manipulation of the mammalian embryo. J. Anim. Sci. 61, Suppl 3, 1-13.

Anderson, G. (1987): Identification of embryonic sex by detection of H-Y antigen. Theriogenology 27, 81-97.

Berg, T., Healy, P. J., Tollersrud, O. K. and Nilssen, O. (1997): Molecular heterogeneity for bovine alpha-mannosidosis: PCR based assays for detection of breed-specific mutations. Res. Vet. Sci. 63, 279-282.

Bilstrom, J. A., Valberg, S. J., Bernoco, D. and Mickelson, J. R. (1998): Genetic test for myophosphorylase deficiency in Charolais cattle. Am. J. Vet. Res. 59, 267-270.

Bols, P. E. J., Vandenheede, J. M. M., Van Soom, A. and de Kruif, A. (1995): Transvaginal ovum pick-up (OPU) in the cow: a new disposable needle guidance system. Theriogenology $\mathbf{4 3}$, 677-687.

Brackett, B. G., Bousquet, D., Boice, M. L., Donawick, W. J., Evans, J. F. and Dressel, M. A. (1982): Normal development following in vitro fertilization in the cow. Biol. Reprod. 27, $147-158$.

Bradbury, M. W., Isola, L. M. and Gordon, J. W. (1990): Enzymatic amplification of a Y chromosome repeat in a single blastomere allows identification of the sex of preimplantation mouse embryos. Proc. Natl. Acad. Sci. USA 87, 4053-4057.

Bredbacka, P. (1998): Recent developments in embryo sexing and its field application. Reprod. Nutr. Dev. 38, 605-613.

Bredbacka, P., Kankaanpää, A. and Peippo, J. (1995): PCR-Sexing of bovine embryos: A simplified protocol. Theriogenology 44, 167-176.

Carbonneau, G., Morin, N., Durocher, J. and Bousquet, D. (1997): Viability of bovine IVF embryos biopsied with microsection or microaspiration technique for sexing. Theriogenology 47, 266.

Chan, A. W., Kukolj, G., Skalka, A. M. and Bremel, R. D. (1999): Timing of DNA integration, transgenic mosaicism, and pronuclear microinjection. Mol. Reprod. Dev. 52, 406-413.

Cotinot, C., Kirszenbaum, M., Leonard, M., Gianquinto, L. and Vaiman, M. (1991): Isolation of bovine Y-derived sequence: potential use in embryo sexing. Genomics 10, 646-653.

Fésüs, L. (1997): Marker assisted selection in livestock. $1^{\text {st }}$ paper: theoretical aspects (in Hungarian). Állatteny. Takarm. (Hung. J. Anim. Prod.) 46, 289-292.

Fésüs, L., Anton, I. and Zsolnai, A. (1999): Marker assisted selection in livestock. $4^{\text {th }}$ paper: Incidence of DUMPS, Weaver-sickness and citrullinaemia in cattle populations (in Hungarian). Állatteny. Takarm. (Hung. J. Anim. Prod.) 48, 193-203.

Handyside, A. H., Lesko, J. G., Tarín, J. J., Winston, R. M. and Hughes, M. R. (1992): Birth of a normal girl after in vitro fertilization and preimplantation diagnostic testing for cystic fibrosis N. Engl. J. Med. 327, 905-909.

Handyside, A. H., Pattinson, J. K., Penketh, R. J., Delhanty, J. D., Winston, R. M. and Tuddenham, E. G. (1989): Biopsy of human preimplantation embryos and sexing by DNA amplification. Lancet 1, No. 8634, 347-349.

Harper, P. A., Healy, P. J., Dennis, J. A., O’Brien, J. J. and Rayward, D. H. (1986): Citrullinaemia as a cause of neurological disease in neonatal Friesian calves. Aust. Vet. J. 63, 378-379.

Herr, C., Holt, N., Matthaei, K. and Reed, K. (1990): Sex of progeny from bovine embryos sexed with a rapid $\mathrm{Y}$-chromosome detection assay. Theriogenology 33, 247.

Heyman, Y. (1999): Overall bovine embryo transfer activity in Europe in 1998. Proceedings of the $15^{\text {th }}$ Scientific Meeting of the European Embryo Transfer Association, Lyon, France, 1011 Sept. 52, 25-69. 
Hochman, D., Zaron, Y., Dekel, I., Feldmesser, E., Medrano, J., Shani, M. and Ron, M. (1996): Multiple genotype analysis and sexing of IVF bovine embryos. Theriogenology 46, 1063-1075.

Horvat, S., Medrano, J. F., Behboodi, E., Anderson, G. B. and Murray, J. D. (1993): Sexing and detection of gene construct in microinjected bovine blastocysts using the polymerase chain reaction. Transgenic Res. 2, 134-140.

Hyttinen, J. M., Peura, T., Tolvanen, M., Aalto, J., Alhonen, L., Sinervirta, R., Halmekytö, M., Myöhänen, S. and Jänne, J. (1994): Generation of transgenic dairy cattle from transgeneanalyzed and sexed embryos produced in vitro. Biotechnology (N Y) 12, 606-608.

Hyttinen, J. M., Peura, T., Tolvanen, M., Aalto, J. and Jänne, J. (1996): Detection of microinjected genes in bovine preimplantation embryos with combined DNA digestion and polymerase chain reaction. Mol. Reprod. Dev. 43, 150-157.

Jánosa, A., Baranyai, B. and Dohy, J. (1999): Comparison of milk production of the progeny of BLAD-carrier and healthy Holstein bulls in Hungary. Acta Vet. Hung. 47, 291-302.

Jörgensen, C. B., Agerholm, J. S., Pedersen, J. and Thomsen, P. D. (1993): Bovine leukocyte adhesion deficiency in Danish Holstein-Friesian cattle. I. PCR screening and allele frequency estimation. Acta Vet. Scand. 34, 231-236.

Macháty, Z., Páldi, A., Csáki, T., Varga, Z., Kiss, I., Bárándi, Z. and Vajta, G. (1993): Biopsy and sex determination by PCR of IVF bovine embryos. J. Reprod. Fertil. 98, 467-470.

Munné, S., Tang, Y. X., Grifo, J., Rosenwaks, Z. and Cohen, J. (1994): Sex determination of human embryos using the polymerase chain reaction and confirmation by fluorescence in situ hybridization. Fertil. Steril. 61, 111-117.

Mullis, K. and Faloona, F. A. (1987): Specific synthesis of DNA in vitro via a polymerasecatalyzed chain reaction. Methods Enzymol. 155, 335

Ozil, J. P., Heyman, Y. and Renard, J. P. (1982): Production of monozygotic twins by micromanipulation and cervical transfer in the cow. Vet. Rec. 110, 126-127.

Penketh, R. J., Delhanty, J. D., van den Berghe, J. A., Finklestone, E. M., Handyside, A. H., Malcolm, S. and Winston, R. M. (1989): Rapid sexing of human embryos by nonradioactive in situ hybridization: potential for preimplantation diagnosis of X-linked disorders. Prenat. Diagn. 9, 489-499.

Peura, T., Hyttinen, J. M., Turunen, M. and Jänne, J. (1991): A reliable sex determination assay for bovine preimplantation embryos using the polymerase chain reaction. Theriogenology $\mathbf{3 5}$, $47-55$.

Picard, L., King, W. A. and Betteridge, K. J. (1985): Production of sexed calves from frozenthawed embryos. Vet. Rec. 117, 603-608.

Robinson, J. L. and Shanks, R. D. (1993): Low Incidence of Citrullinemia in U.S. Dairy Cattle. Dairy Cattle Genetics and Selection Collection: Gen. Impr. U.S. National Dairy Database http://www.inform.umd.edu/EdRes/Topic/AgrEnv/ndd

Schellander, K., Mayr, B., Ertl, K. and Peli, J. (1993): Simultaneous genotyping of sex and kappa-casein of bovine in vitro fertilized embryos by the PCR technique. Zbl. Vet.-med. A 40, 307-309.

Schwenger, B., Tammen, I. and Aurich, C. (1994): Detection of the homozygous recessive genotype for deficiency of uridine monophosphate synthase by DNA typing among bovine embryos produced in vitro. J. Reprod. Fertil. 100, 511-514.

Schwerin, M., Parkanyi, V., Roschlau, W., Kanitz, W. and Brockmann, G. (1994): Simultaneous genetic typing at different loci in bovine embryos by multiplex polymerase chain reaction. Anim. Biotech. 5, 47-63.

Seike, N., Utaka, K. and Kanagawa, H. (1990): Production and development of calves from sexedbisected bovine embryos. Jpn. J. Vet. Res. 38, 1-9.

Shanks, R. D. and Robinson, J. L. (1993): Five Years of DUMPS Testing. Dairy Cattle Genetics and Selection Collection: Gen. Impr. U.S. National Dairy Database http://www.inform.umd.edu/EdRes/Topic/AgrEnv/ndd

Thomsen, P. D. and Nielsen, J. S. (1991): PCR screening for carriers of hereditary citrullinaemia in Danish Holstein-Friesian bulls. Acta Vet. Scand. 32, 279-282. 
Vajta, G., Holm, P., Greve, T. and Callesen, H. (1997): Comparison of two manipulation methods to produce in vitro fertilized, biopsied and vitrified bovine embryos. Theriogenology 47, 501-509.

Vosberg, H. P. (1989): The polymerase chain reaction: an improved method for the analysis of nucleic acids. Hum. Genet. 83, 1-15.

Wachtel, S., Nakamura, D., Wachtel, G., Felton, W., Kent, M. and Jaswaney, V. (1988): Sex selection with monoclonal H-Y antibody. Fertil. Steril. 50, 355-360.

Wilton, L. J. and Trounson, A. O. (1989): Biopsy of preimplantation mouse embryos: development of micromanipulated embryos and proliferation of single blastomeres in vitro. Biol. Reprod. 40, 145-152.

Wong, C., Dowling, C. E., Saiki, R. K., Higuchi, R. G., Erlich, H. A. and Kazazian, H. H. J. (1987): Characterization of beta-thalassaemia mutations using direct genomic sequencing of amplified single copy DNA. Nature 330, 384-386.

Yadav, B. R., King, W. A., Xu, K. P., Picard, L. and Betteridge, K. J. (1990): Sex ratio of bovine embryos produced by fertilization in vivo and in vitro. Theriogenology 33, 356 .

Zsolnai, A. and Fésüs, L. (1996): Simultaneous analysis of bovine kappa-casein and BLAD alleles by multiplex PCR followed by parallel digestion with two restriction enzymes. Anim. Genet. 27, 207-209.

Zsolnai, A. and Fésüs, L. (1997): Enhancement of PCR-RFLP typing of bovine leukocyte adhesion deficiency. Biotechniques 23, 380-382. 